Tin Matulja, Ph.D.

E-mail: tin.matulja@riteh.hr

Marko Hadjina, Ph.D.

E-mail: hadjina@riteh.hr

Damir Kolić, Ph.D.

E-mail: damir.kolic@riteh.hr

University of Rijeka, Faculty of Engineering, Vukovarska 58, 51000 Rijeka, Croatia

\title{
Shipyard Production Processes Re-Design Methodology Based on Expert Approach and Simulation Modeling
}

\begin{abstract}
The authors propose a synergy of expert approach methods through the Systematic layout planning (SLP) and Analytic Hierarchy Process (AHP) as tools for the shipyard production process design towards an optimal material flow, in combination with Simulation modeling (SM). Most production process designs are based on the conventional methodology of comparison initiating with benchmarking. Such approach can be misleading. For more reliable and efficient results, the approach suggested by the authors uses a combination of the mentioned three methods within the frame of an expert approach. Firstly, the Systematic layout planning is used for generating a larger number of suboptimal shipyard production process design alternatives. Then, these alternatives are analyzed through an objective decision making tool to reach an optimal material flow alternative. Further, such optimal alternative is tested and evaluated by Simulation modeling (SM). Finally, the presented methodology is confirmed on a case study as a viable approach to an efficient and reliable shipyard production process design.
\end{abstract}

Key words: Shipyard production processes re-design, SLP method, AHP method, Simulation modeling

\section{Introduction}

Production process design with optimal material flow is geared towards seeking optimal solutions for different activities with corresponding components. This process understands finding spatial arrangement of such activities in a given space, satisfying given preferences and constraints, [1]. It can be considered as a layout problem. More specifically, it is a complex and subjective problem which includes evolving task 
dynamics, inadequate information availability, as well as uncertain and conflicting preferences, [2].

It is obvious that the production process design and material flow could be based on designer's creativity and interaction between results of different contradictory disciplines, [3]. It is a known fact that the majority of software's and computerized techniques for such design ignore creativity, knowledge and experience of experts who understand the complex interaction between the production flow and production areas. Still, there is an approach which includes expert knowledge for decision making and modeling of such uncertain problems, [4]. Such an Expert system approach can be applied in generating and analyzing design alternatives of the production process material flow.

Every production process has characteristic production areas to be placed into the given space, [5]. Configuration of such areas can be an especially interesting problem due to specific characteristics of different production processes which can involve even large scale products that require wide production areas. The need for investigating such specific problem arises from few basic reasons:

1) The size and shape of existing production process areas are often unchangeable because they are bounded by the sea on one side and by urban settlements and/or industrial facilities on the other;

2) The layout of existing production facilities is usually not subject to changes due to large scale structures and already established corresponding infrastructure;

3) Evolution of production technology caused different demands and requirements for production areas. Such demands are difficult to implement because of already specified constraints and limitations.

Due to mentioned reasons, technological modernization within the existing production process has to be oriented toward improving the efficiency in using the existing production areas.

For that purpose, it is suggested that at the end the Simulation modeling SM be used as a tool for verification and optimal dimensioning of material flows within the production process.

The presented methodology is shown on a case study as a viable approach toward an efficient and reliable production process design. It features both the simplicity of the design process and the objectivity of the multiple-criteria decision making and evaluation process.

\section{Expert approach in production process design}

Every production process includes: Relationship between selected production areas, Size and shape of particular production area, Spatial arrangement of production areas within the layout. Taking in consideration these elements, the goal is procedurally obtained. 


\subsection{Generation of shipyard design alternatives by SLP method}

Firstly, the goal is generation and selection of acceptable and most feasible shipyard production process configurations by analyzing all possible combinations of material flows. There is a very large number of such combinations, for example, for 15 shipyard production areas that can be considered there are $1.3 \times 10^{12}$ mathematically possible alternatives.

All generated configurations as shipyard design solutions can be evaluated by a score, calculated according to closeness criteria based on weight factors as follows:

$$
s=\sum_{i=1}^{n_{p}} w_{i} \cdot Y_{i}
$$

where

$Y_{i}=$ number of closeness of i-class,

$\mathrm{w}_{\mathrm{i}}=$ weight factor for $\mathrm{i}$-closeness,

$\mathrm{s}=$ SLP score,

$\mathrm{n}_{\mathrm{p}}=$ number of production areas.

Weight factors can be calculated using following relation:

$$
w_{i}=\frac{\sum_{k=1}^{m} \rho_{j k}}{m}
$$

where

$\mathrm{w}_{\mathrm{i}}=$ weight factor for $\mathrm{i}$-th closeness,

$\rho_{\mathrm{jk}}=$ closeness rating for $\mathrm{i}$-th closeness form $\mathrm{k}$-th expert,

$\mathrm{m}$ - number of experts.

Those weight factors should be defined using survey method among large number of relevant experts from the shipbuilding production field as well as relevant experts from universities. An adequate questionnaire is prepared including closeness ratings for each interacting production area as the basis for optimal material flow generation, see figure 1 .

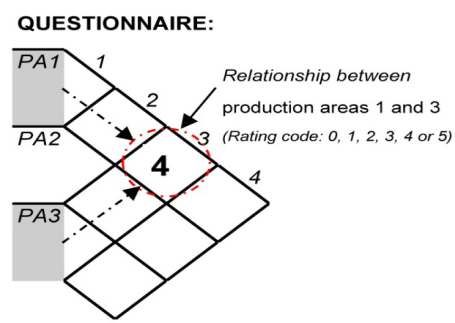

Fig. 1 Example of questionnaire used within survey method among large number of relevant experts 
The shipyard production areas $\left(\mathrm{PA}_{\mathrm{n}}\right)$ which are directly participating in the basic production process was selected and compared. The combination of these production areas directly changes the basic production flow and therefore influence on the shipyard production process. In that context, it is necessary to identify closeness ratings with corresponding weight factors for every interaction of areas from 1 to $\mathrm{n}$. Closeness ratings are described with code numbers $0,1,2,3,4$ and 5 , and the processed results of an expert survey using the presented questionare can be presented as shown in Figure 2.

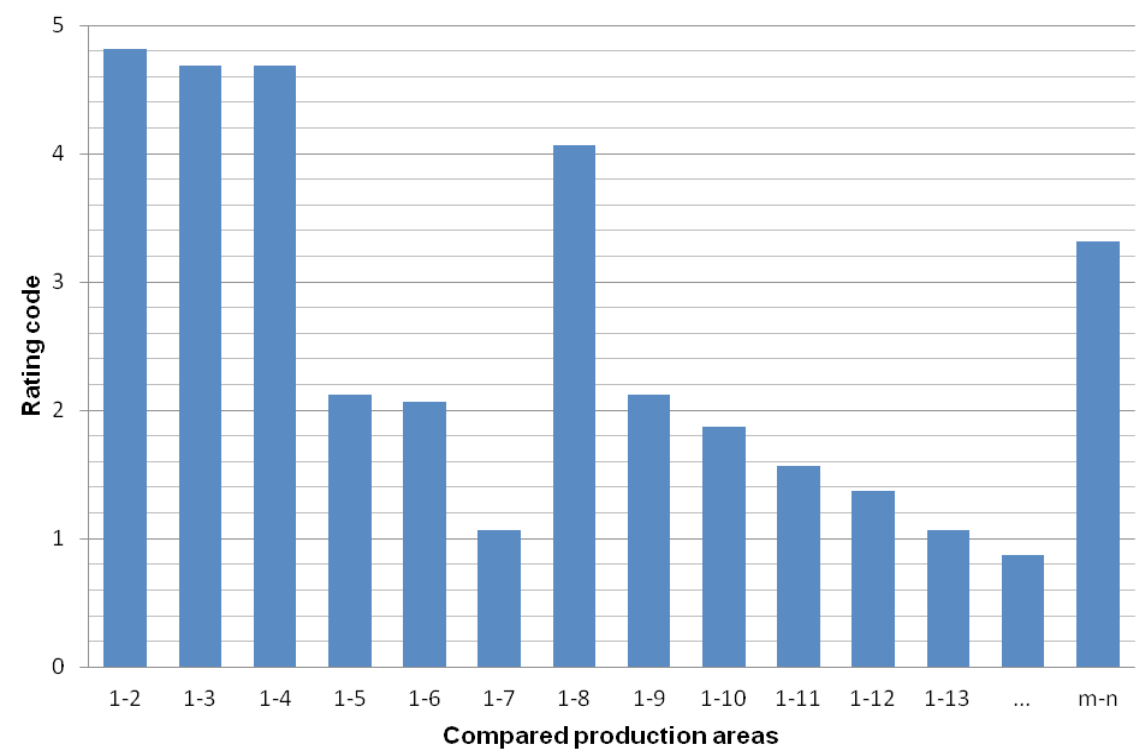

Fig. 2 Obtained codes using survey method

Every rating code has a closeness rating defined by the code letter description and accompained by the weight factor that is also defined for the known production field through the survey method among a large number of relevant experts. Such weight factor represents the calculation input data for next steps of the proposed methodology, Table 1.

Table 1 Closeness description and obtained weight factors using survey method

\begin{tabular}{|c|c|l|c|}
\hline Rating Code & Rating Letter & Closeness & Weight factor, wi \\
\hline 5 & A & Absolutely necessary & 45 \\
\hline 4 & E & Especially important & 11 \\
\hline 3 & I & Important & 3 \\
\hline 2 & O & Ordinary & 1 \\
\hline 1 & U & Unimportant & 0 \\
\hline 0 & X & Not desirable & -45 \\
\hline
\end{tabular}


Data collected by the survey method of relevant experts were used within the SLP method for generation of all possible design solutions. Such possible design solutions should be analyzed regarding the optimal production flow as defined by expert's relationship matrix as shown in Table 2.

Table 2 Experts relationship matrix as basis for SLP method application

\begin{tabular}{|l|c|c|c|c|c|c|c|}
\hline Production area & 1 & 2 & 3 & 4 & 5 & $\ldots$ & $n p$ \\
\hline PA1 & + & A & A & A & O & O & U \\
\hline PA2 & & + & I & I & I & E & U \\
\hline PA3 & & & + & I & E & E & U \\
\hline PA4 & & & & + & A & E & U \\
\hline PA5 & & & & & + & A & I \\
\hline$\ldots$ & & & & & & + & $\ldots$ \\
\hline PAnp & & & & & & & + \\
\hline
\end{tabular}

One of the generated alternatives of shipyard production areas will certainly be the best regarding the SLP score, i.e. regarding the optimal production flow, as shown in Figure 3, but it is not necessarily an optimal solution regarding the overall production requirements. Namely, beside the requirements for optimal production flow, for re-design of the existing shipyard production process, other important requirements and constraints have to be taken in consideration.

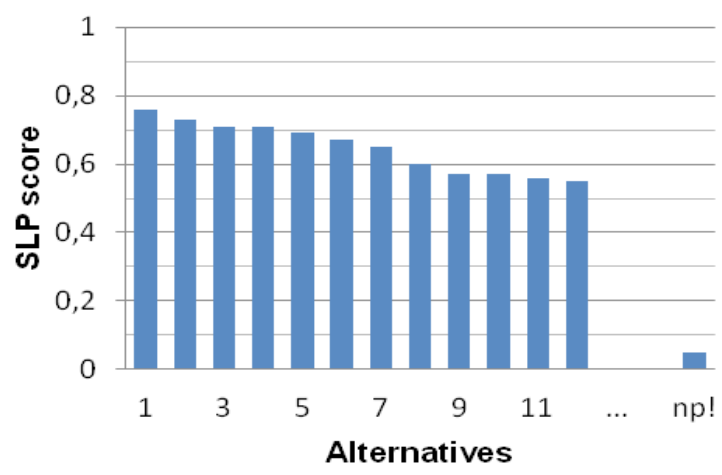

Fig. 3 Ranking list of generated alternatives regarding SLP score

Therefore, within this phase the authors suggest selection of a few to maximally 20 best feasible design alternatives regarding the SLP score, because this is the sample where the design solution which optimally meets all constraints and limitations is most likely expected. 


\subsection{Selection of the optimal layout design alternative by AHP}

For an optimal design solution selection, the Analytical Hierarchy Process (AHP) is suggested. The AHP method is one of the multi-attribute decision making approaches. It is a structured technique for dealing with complex decisions, [6]. The hierarchical model structurally consists of the following levels: a goal, criteria, sub-criteria and alternatives (solutions), Figure 4. The goal is placed on the highest hierarchical level and it is not compared to any other element of the hierarchical structure. On the first level, there are $\mathrm{k}$ criteria which are compared to each other in pairs regarding the directly superior element - the goal. The $k \cdot(k-1) / 2$ of comparisons is required. The same procedure is repeated for the next hierarchical level, all the way down to the last $\mathrm{r}$ level, until all comparisons of all solutions with respect to the superior criteria, down to $\mathrm{r}-1$ level, have been completed.

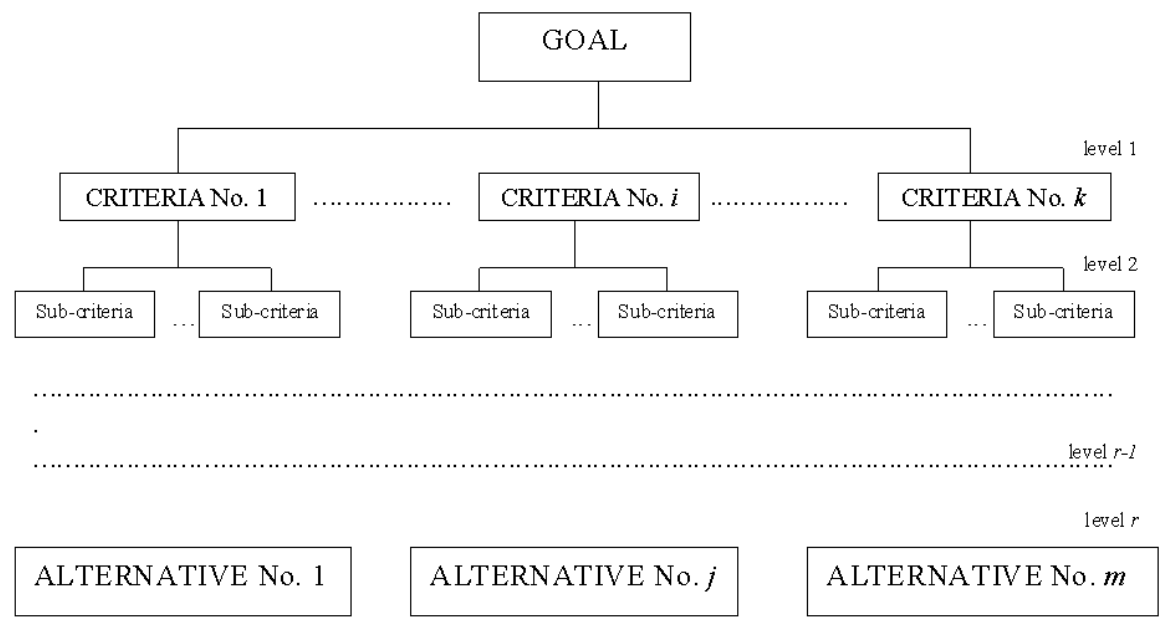

Fig 4 Analytical Hierarchy Process model, [6]

Each comparison of two elements of the hierarchical model is made using the Saaty's scale of relative importance as shown in Table 4. 
Table 4 Saaty's scale of relative importance, [6]

\begin{tabular}{|l|l|l|}
\hline $\begin{array}{l}\text { Intensity } \\
\text { of relative } \\
\text { importance }\end{array}$ & Definition & Explanation \\
\hline 1 & Equal importance & $\begin{array}{l}\text { Two activities contribute equally to the } \\
\text { objective }\end{array}$ \\
\hline 3 & $\begin{array}{l}\text { Moderate importance of one } \\
\text { over another }\end{array}$ & $\begin{array}{l}\text { Experience and judgment slightly } \\
\text { favour one activity over another }\end{array}$ \\
\hline 5 & Essential or strong & $\begin{array}{l}\text { Experience and judgment strongly } \\
\text { favour one activity over another }\end{array}$ \\
\hline 7 & Very strong importance & $\begin{array}{l}\text { An activity is strongly favoured and its } \\
\text { dominance is demonstrated in practice }\end{array}$ \\
\hline 9 & Extreme importance & $\begin{array}{l}\text { The evidence favouring one activity } \\
\text { over another is of the highest possible } \\
\text { order of affirmation }\end{array}$ \\
\hline $2,4,6,8$ & $\begin{array}{l}\text { Intermediate values between } \\
\text { two adjacent judgments }\end{array}$ & $\begin{array}{l}\text { When compromise is needed between } \\
\text { two judgments }\end{array}$ \\
\hline
\end{tabular}

The results of elements comparison on the observed hierarchical level are organised in matrix form as follows:

If $\mathrm{n}$ elements are compared to each other with respect to the superior corresponding element on a higher hierarchical level, then, when comparing i element to $j$ element using Saaty's scale of relative importance, numerical coefficient aij is determined and placed in its adequate position in matrix A:

$$
A=\left[\begin{array}{ccccc}
a_{11} & a_{12} & \cdot & \cdot & a_{1 n} \\
a_{21} & a_{22} & \cdot & \cdot & a_{2 n} \\
\cdot & \cdot & & & \cdot \\
\cdot & \cdot & & & \cdot \\
a_{n 1} & a_{n 2} & \cdot & \cdot & a_{n n}
\end{array}\right]
$$

The inverse result value is placed to position aji as to maintain the consistency of decision making. Detailed description of AHP method can be found in [6].

In order to select the optimal design between the preselected probable design alternatives, it is necessary to define the relevant criteria, constraints and limitations. Usually, the criteria relevant for re-design of the existing shipyard production process are:

$\mathrm{C}_{1}=$ SLP score,

$\mathrm{C}_{2}=$ Investment limitations,

$\mathrm{C}_{3}=$ Influence on ongoing production process,

$\mathrm{C}_{4}=$ retaining the existing facility boundaries, etc.,

$\mathrm{C}_{\mathrm{k}}=\mathrm{k}$-th criteria 
Detailed analysis of selected design solutions regarding the selected criteria should be then performed. The results format is shown in Figure 5.

\begin{tabular}{|c|c|c|c|c|c|c|c|}
\hline \multirow[b]{2}{*}{$\begin{array}{l}\text { Weight } \\
\text { factor }\end{array}$} & & & \multicolumn{5}{|c|}{ Alternatives } \\
\hline & & & 1 & 2 & $\ldots$ & 7 & 20 \\
\hline 0,11 & & $\mathrm{C}_{1}$ & 0,65 & 0,76 & $\ldots$ & 0,69 & 0,57 \\
\hline 0,43 & & $\mathrm{C}_{2, \mathrm{k} \in}$ & 24859 & 26177 & $\ldots$ & 20974 & .. 27797 \\
\hline 0,19 & $\frac{0}{2}$ & $\mathrm{C}_{3, \%}$ & 30 & 30 & $\ldots$ & 10 & $\ldots 90$ \\
\hline 0,27 & : & $\mathrm{C}_{4}$ & $\mathrm{~N}$ & Y & $\ldots$ & $\mathrm{N}$ & $\ldots$ \\
\hline$\ldots$ & & $\ldots$ & $\cdots$ & $\cdots$ & $\ldots$ & $\cdots$ & $\ldots$ \\
\hline$\cdots$ & & $\mathrm{C}_{\mathrm{k}}$ & $\cdots$ & $\cdots$ & $\cdots$ & $\cdots$ & $\cdots$ \\
\hline
\end{tabular}

Fig. 5 Relationship matrix for AHP

Each alternative can be compared with regard to the selected criteria, as shown for real case study in the following figures. It can be seen that, regarding the selected comparison of real case study, some alternatives show low investments and relatively high SLP score, Figure 6, or some alternatives show low investment costs without any significant influence on the ongoing production process, Figure 7., etc.

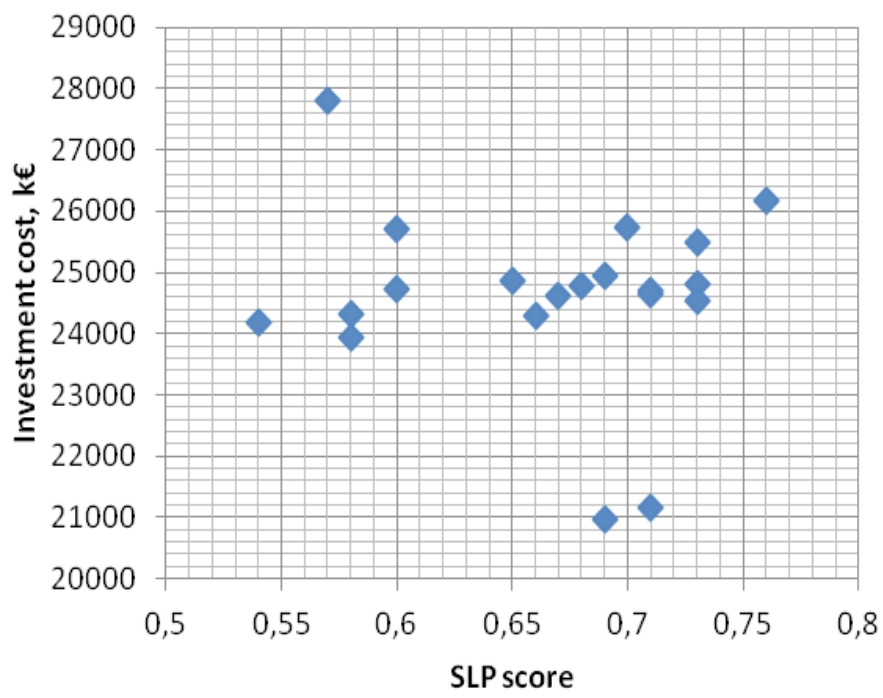

Fig. 6 Alternative comparison regarding criterion $C 1$ and $C 2$ 


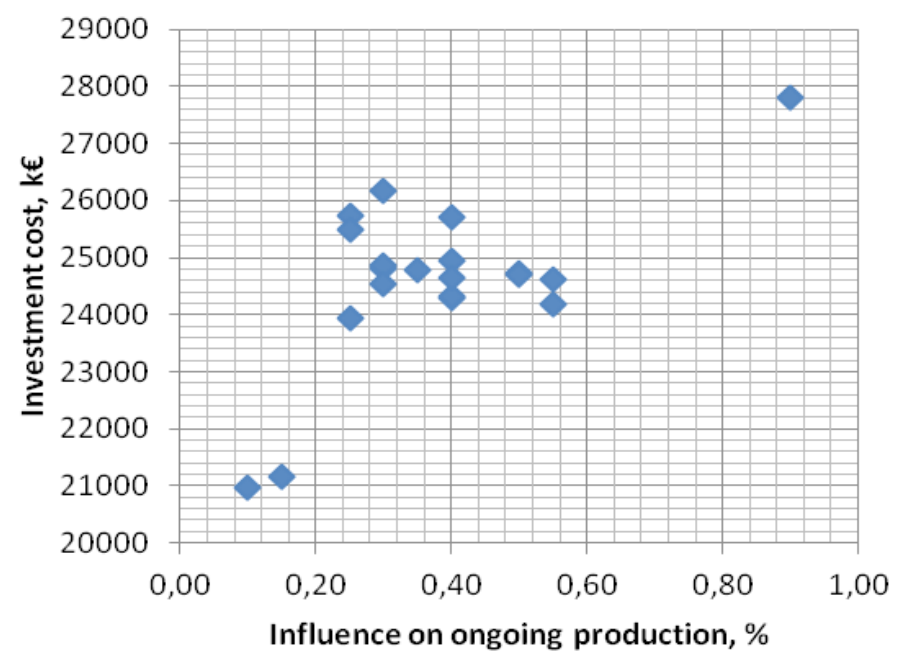

Fig. 7 Alternative comparison regarding criterion $C 2$ and $C 3$

All criteria are included in the hierarchical model development and, based on them, an optimal design solution by AHP method is found among the chosen design alternatives. The AHP method is conducted through specialized software, [7]. Furthermore, for confirming the robustness of selected design solution, the performance sensitivity analysis (SA) is performed, [8]. The results for the case study are shown graphically in Figure 8.

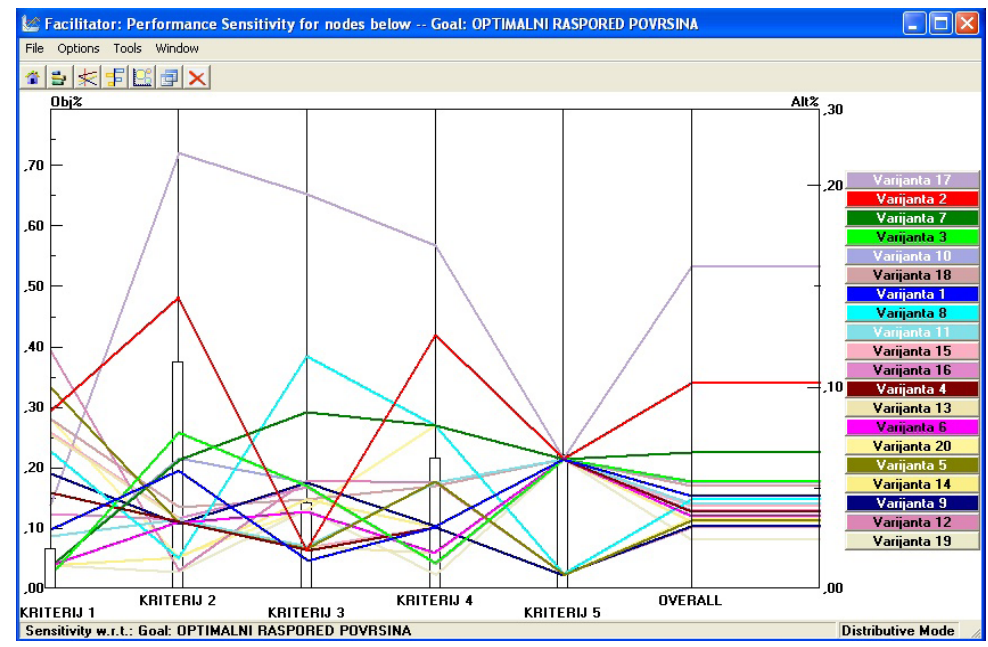

Fig. 8 Results of performance $S A$ 
The final results of proposed alternatives regarding overall priorities for the real shipyard are shown as a ranking list in Figure 9.

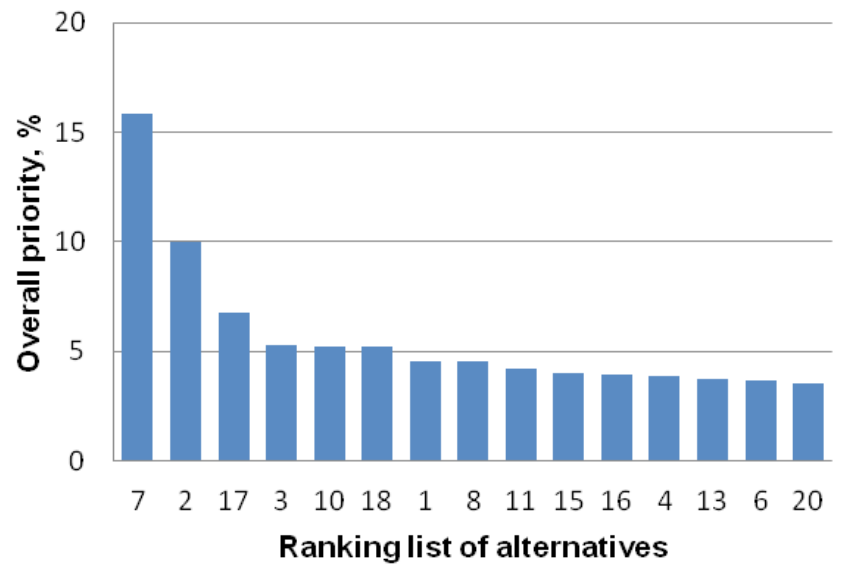

Fig. 9 Ranking list of proposed alternatives regarding overall priorities

Schematic material flow for optimal alternative number 7 developed within SLP method is used as basis for further Simulation modeling as tool for optimizing and balancing the production process defining the throughputs of material flows. In such a way the production areas, machinery and other technological considerations can be optimized regarding defined productivity and product mix.

\subsection{Design solution verification by Simulation modeling}

For simulation modeling an object oriented, a discrete event simulation modeling software is used, [9]. The basic element of the simulation modeling method is the computer simulation model of the designed shipyard production process. Such computer simulation model, compared to the traditional analysis model is more descriptive, more manageable and allowing designers to verify various decision alternatives on computer, fast and in early design stages, [10]. For that matter, some of the most significant reasons why the simulation modeling method is suggested as a method for verification of the shipyard production process design are, [11]:

- Simulation model is a relatively true presentation of the real process;

- Using the computer simulation model, it is possible to spot the process bottlenecks on the process computer model, before they happen in the real process;

- Computer simulation model can be used for evaluating different design alternatives (what-if scenarios) prior to the final investment; 
- Computer simulation model can be used for verification of suggested solutions to the identified problem in real production or for experimenting with certain critical equipment parameters without influencing the real process, etc.

Such approach provides the production management with lots of relevant and timely information enabling more reliable decisions which will lead to the solution optimally adapted to the observed production process, [12]. Therefore, following the suggested design alternative, the authors suggest a computer simulation modeling for the development of a conceptual simulation model of the suggested shipyard layout for the purpose of balancing workshop requirements for working hours and workers at the preliminary level for the selected product mix and planned production capacity of processed steel per year.

\section{Conceptual simulation model of suggested layout}

Conceptual simulation model of the proposed layout was developed using specialized simulation modeling software. For this level of modeling, productions areas are defined based on alternative number 7. Equipment characteristics and its parameters of individual workshops as input data for simulation model are defined according to expert approach and by comparison with similar production processes.

The purpose of such conceptual simulation model is to verify dimensions of the needed production areas, man hours and man power, through various scenarios and variations for the chosen input parameters, with regard to the targeted process throughput per year. Furthermore, such conceptual model is the basis for further detailed modeling of all production areas with the purpose of defining the detailed parameters of the process, its optimization and management.

\section{Input data for conceptual simulation model}

Initial input data variables and their parameters for conceptual simulation model have to be defined according to the material flow of the considered shipyard production process and experts survey. An example of the input variables and its typical parameters which were assessed for entry stage into the conceptual simulation model are shown in table 5. The simulation model developed using such data is processed through different scenarios, and initial parameters should be changed and balanced in order to the target throughput for 250 working days in a shift of $7.5 \mathrm{~h}$ with the highest number of available production workers. In this context, the implementation of different scenarios varying the selected parameters in this conceptual phase will assess the need for effective working hours and number of workers or robots per workshop. Such model could be the foundation for further simulation modeling of each individual production area, to define the detailed characteristics of certain parts of the production process. 
Table 5 Initial data variables in production process with assessed typical parameters

\begin{tabular}{|l|}
\hline Production process stage \\
\hline Plates - fabrication \\
Gross material weight \\
Estimated average dimensions \\
Number of average elements \\
Average element fabrication time \\
\hline Profiles - fabrication \\
Gross material weight \\
Estimated average dimensions \\
Number of average elements \\
Average element fabrication time \\
\hline Automatic fabrication line \\
Weight of elements for fabrication line \\
Estimated average elements dimensions \\
Number of average elements \\
Average element fabrication time \\
\hline Subassembly \\
Number of subassembly elements \\
Estimated average subassembly element \\
Average subassembly element fabrication time \\
\hline Assembly \\
Total weight of constructed block of elements \\
Estimated average block dimensions \\
Average block fabrication time. \\
\hline
\end{tabular}

\section{Developed conceptual simulation model and results}

The conceptual simulation model of the selected production process, based on the input variables and its parameters assessed as discussed in the previous section, is developed, see Figure 10. The production areas included in the model represent a stockyard, Plates - cutting and forming, Profiles - cutting and forming, subassembly line, automatic fabrication line and assembly line. 


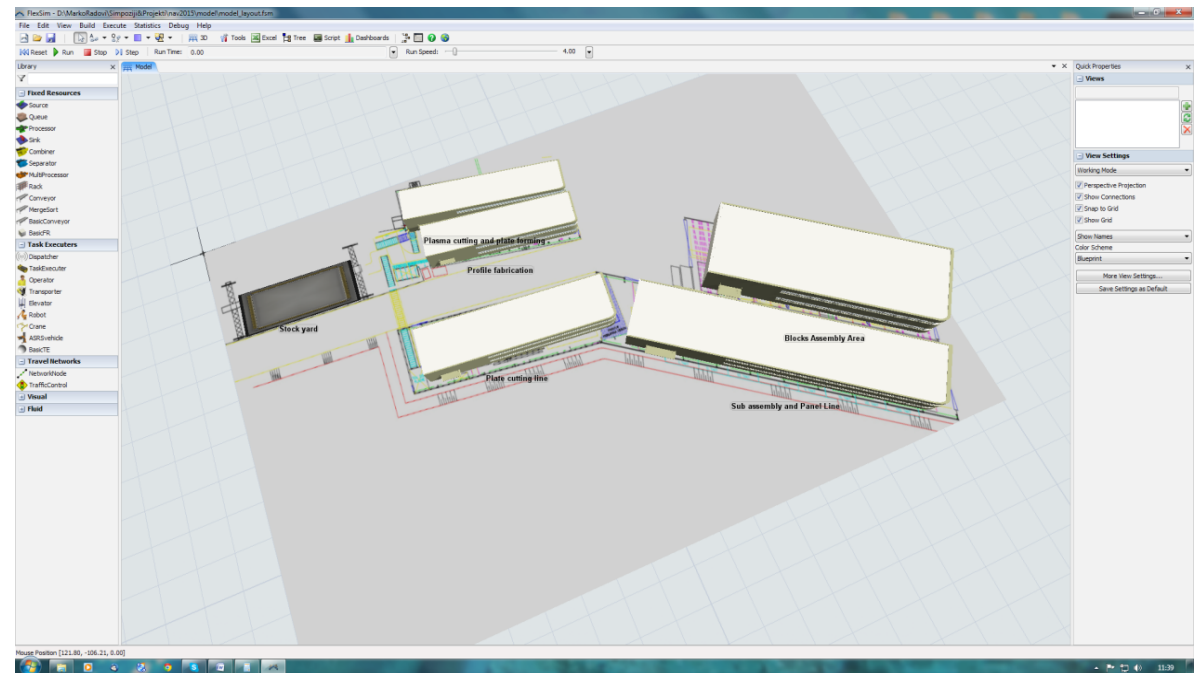

Fig. 10 Conceptual simulation model of selected production process

Once the model is completed and tested, a number of scenarios can be conducted changing its major parameters according to Table 6 . The purpose of such variation of parameters is to estimate adequate values of the effective working hours per year for each workshop and the needed manpower for a targeted capacity and available production workers.

Table 6 The range of variation of chosen initial parameters of conceptual layout simulation model

\begin{tabular}{|l|c|}
\hline Parameter & Range of variation \\
\hline Average plate fabrication time & $20 \%$ \\
\hline Average profile fabrication time & $30 \%$ \\
\hline Average automated fabrication line time & $20 \%$ \\
\hline Average subassembly fabrication time & $30 \%$ \\
\hline Average block fabrication time & $40 \%$ \\
\hline
\end{tabular}

Conducting various combinations of scenarios with variation of parameters, the effective working hours for production areas are estimated and the required number of production workers for the targeted productivity is defined. Table 7 shows the estimated effective operating hours and the number of required production workers at each production area. 
Table 7 Estimated effective working hours and the number of workers per production area

\begin{tabular}{|l|l|l|}
\hline Production phase & E.h./year & Workers \\
\hline Plate fabrication & 15000 & 8 \\
\hline Profile fabrication & 11250 & 6 \\
\hline Element 1 forming & 7500 & 4 \\
\hline Element 2 forming & 9375 & 5 \\
\hline Autom. fabrication line & 15000 & 8 \\
\hline Subassembly & 37500 & 20 \\
\hline Assembly & 168750 & 90 \\
\hline TOTAL & 264375 & 141 \\
\hline
\end{tabular}

Such results obtained using the suggested methodology are compared with the real present throughput and effective working hours before the re-design of the existing real shipyard production process as shown in table 8 and the improvement is presented on Figure 11.

Table 8 Comparison of results before and after re-design

\begin{tabular}{|l|l|l|l|}
\hline Production process & Throughput, t/year & E.h/year & E.h/t \\
\hline Before (real case data) & 4200 & 285000 & 68 \\
\hline After (simulation data) & 6000 & 264375 & 44 \\
\hline
\end{tabular}

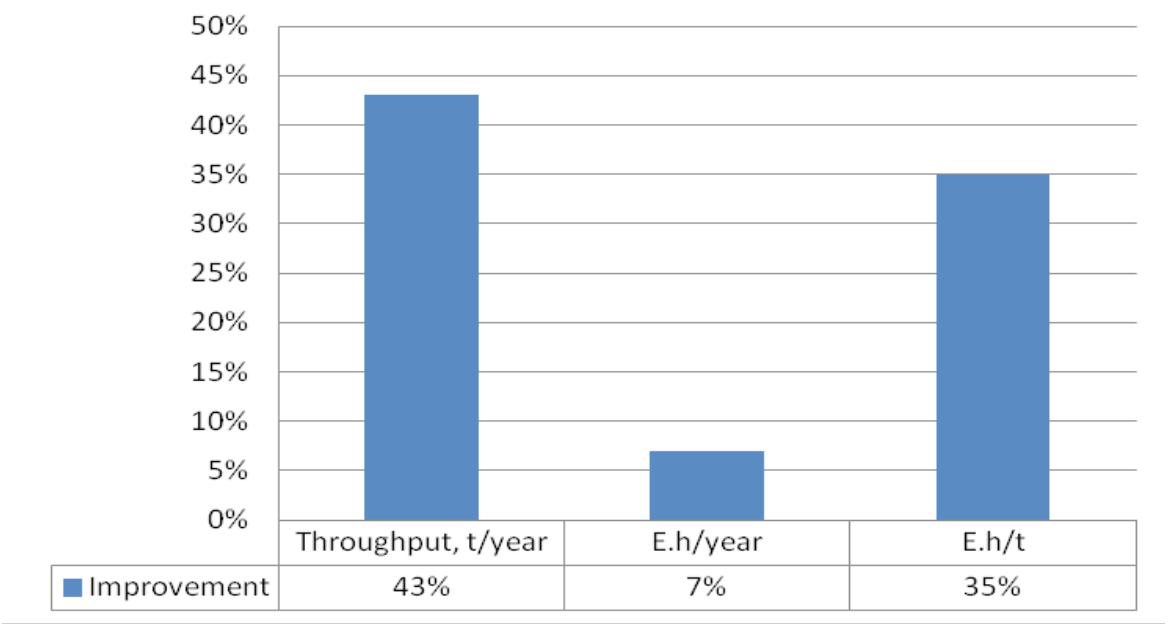

Fig. 11 Improvement over previous state 
Further, detailed development of the selected production process design is possible by simulating the process within each production area to define in more details the process characteristics regarding the type of equipment and its parameters, production surfaces, internal material flow, capacity of equipment and surfaces, etc.

\section{Conclusion}

Most of production process designs are based on the conventional methodology initiating with benchmarking. Such approach can be misleading. For more reliable and efficient results, the authors presented an approach by using a synergy of expert approach methods through Systematic layout planning (SLP) and Analytic Hierarchy Process (AHP) as tools for the production process design towards an optimal material flow. In the first place the SLP method was used for generation of possible design alternatives. Using input parameters derivates from the expert approach by interviewing relevant experts, the guide to the optimal material flow was obtained. Furthermore, by including relevant limitations and constraints within the real problem, the AHP method was introduced for the selection of an optimal design alternative. Such optimal design alternative then was optimized using the Simulation modeling method to reach balanced throughput parameters of the production process. This methodology was verified on a real problem within the project of technological re-design of an existing production process. The application of the developed methodology resulted in such a design solution which improved the material flow and at the same time satisfied optimally all the given constraints. Such a design solution was the basis for further detailed calculations.

Furthermore, for the future research the authors suggest application of this methodology for optimization of the material flow within particular production areas of a production process.

\section{Acknowledgments}

The presented paper was conducted with financial support from the University of Rijeka under the project Ship Production Design Methodology Improvement, number 13.09.1.1.06. of 2015. 


\section{References}

1. Karray, F., Zaneldin E., Hegazy T., Shabeeb, A.H.M.And Elbelgati, E., 2000. Tools of Soft Computing as Applied to the Problem of Facilities Layout Planning. IEEE Transaction on Fuzzy Systems, Vol. 8, No. 4, p. 367-379.

2. Epstein, S. L., Moulin, B., Chaker, W., Glasgow, J. I., Gancet, J., 2001. Pragmatism and Spatial Layout Design, COSIT 2001, p.189-205.

3. Tompkins, J.A., White, J.A., Bozer, Y.A., and Tanchoco, J.M.A., 2010. Facilities Planning, 4th Ed. ISBN: 978-0-470-44404-7, John Wiley Inc., NY.

4. Donaghey, E., C.; Chung, A., C.; Kong, H.; Pire, F., V., 2006. "BlockPlan 1.5", Department of Industrial Engineering, Cullen College of Engineering, University of Houston.

5. Young Joo Song, Jong Hun Woo, 2013. New Shipyard Layout Design for the Preliminary Phase \& Case Study for the Green Field Project, International Journal of Naval Architecture and Ocean Engineering, Korea, Volume 5, Issue ,1, pp.132-146

6. Saaty, T. L., 1996. Multicriteria Decision Making, ISBN: 0-9620317-2-0, RWS Publications, USA.

7. Expert Choice, Inc., 2013. Expert Choice software, Arlington, VA, USA,

8. Winston, W. L., 2003. Operations Research: Applications and Algorithms, Publisher: Duxbury Press; 4 edition, ISBN: 0534380581.

9. FlexSim Software Products Inc., 1993-2015

10. Wagner, A., Sanchez, P. J., 2007. Fundamentals of Simulation Modeling, Proceedings of 2007 Winter Simulation Conference, pp. 54-62.

11. Bruzzone, A. G. et al, 2006. The vulnerability of supply chain as key factor in supply chain management, Proceedings of summer computer simulation conference, Calgary, Canada, pp. 181-186.

12. Kaarsemaker, J. A. J. et al, 2007. The Benefits of Applying Simulation in Shipbuilding Production: Arguments Based on Examples from Industry, Proceedings of 6th International Conference on Computer and IT Applications in the Maritime Industries, COMPIT 07, pp. 504-512. 


\title{
Metodologija za restrukturiranje proizvodnog procesa brodogradilišta temeljena na ekspertnom pristupu i simulacijskom modeliranju
}

\begin{abstract}
Sažetak
Autori predlažu sinergiju metoda ekspertnog pristupa korištenjem SLP i AHP metode kao alata za projektiranje brodograđevnog proizvodnog procesa i optimalnog toka materijala, a u kombinaciji s metodom simulacijskog modeliranja za verifikaciju predloženih rješenja. Većina postupaka za projektiranje proizvodnih procesa temelji se na konvencionalnoj metodi uspoređivanja. Takav pristup može biti neadekvatan. Za pouzdanije rješenje autori predlažu pristup temeljen na primjeni tri prethodno spomenute metode u okviru ekspertnog pristupa. Prvo, SLP metoda koristi se za generiranje većeg broja mogućih rješenja. Nadalje, ta moguća rješenja se analiziraju primjenom višekriterijske analize kako bi se odabralo optimalno rješenje prvenstveno sa stajališta toka materijala. Takvo odabrano optimalno rješenje se potom verificira metodom simulacijskog modeliranja. Zaključno, predložena metodologija je potvrđena na realnom primjeru kao pouzdana pri projektiranju, odnosno rekonstruiranju proizvodnog procesa brodogradilišta.
\end{abstract}

Ključne riječi: Rekonstruiranje proizvodnog procesa, SLP metoda, AHP metoda, Simulacijsko modeliranje 
